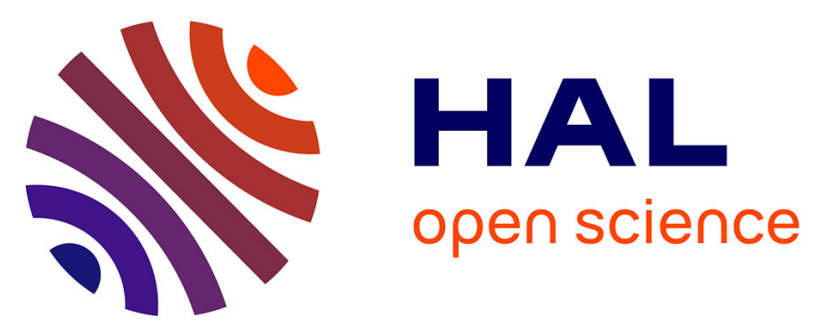

\title{
Role of non-linear oceanic processes in the response to westerly wind events: new implications for the $1997 \mathrm{El}$ Niño onset
}

Jean-Philippe Boulanger, Edmée Durand, Jean-Philippe Duvel, Christophe E. Menkès, Pascale Delécluse, Maurice Imbard, Matthieu Lengaigne, Gurvan Madec, Sébastien Masson

\section{To cite this version:}

Jean-Philippe Boulanger, Edmée Durand, Jean-Philippe Duvel, Christophe E. Menkès, Pascale Delécluse, et al.. Role of non-linear oceanic processes in the response to westerly wind events: new implications for the $1997 \mathrm{El}$ Niño onset. Geophysical Research Letters, 2001, 28 (8), pp.1603-1606. 10.1029/2000GL012364. hal-00153877

\section{HAL Id: hal-00153877 https://hal.science/hal-00153877}

Submitted on 25 Jan 2021

HAL is a multi-disciplinary open access archive for the deposit and dissemination of scientific research documents, whether they are published or not. The documents may come from teaching and research institutions in France or abroad, or from public or private research centers.
L'archive ouverte pluridisciplinaire $\mathbf{H A L}$, est destinée au dépôt et à la diffusion de documents scientifiques de niveau recherche, publiés ou non, émanant des établissements d'enseignement et de recherche français ou étrangers, des laboratoires publics ou privés. 


\title{
Role of non-linear oceanic processes in the response to westerly wind events: new implications for the 1997 El Niño onset
}

\author{
J.-P. Boulanger, and E. Durand \\ Laboratoire d'Océanographie Dynamique et de Climatologie, Unité Mixte CNRS/RD/UPMC, Paris, France
}

J.-P. Duvel,

Laboratoire de Météorologie Dynamique, Unite CNRS, Paris, France

C. Menkes, P. Delecluse, M. Imbard, M. Lengaigne, G. Madec and S. Masson

Laboratoire d'Océanographie Dynamique et de Climatologie, Unité Mixte CNRS/IRD/UPMC. Paris, France

\begin{abstract}
In March 1997, a strong westerly wind event (WWE) occurred in the westem equatorial Pacific prior to the 1997-1998 El Niño event. It produced downwelling Kelvin waves that interacted non linearly with the surface temperature, salinity and zonal current fronts located at the eastern edge of the warm-fresh pool (EEWP). This non-linear interaction locally increased zonal currents by a factor of three compared to a theoretical linear response, and advected the EEWP at an unexpected rate $(\sim 1 \mathrm{~m} / \mathrm{s})$ to which the ocean-atmosphere coupled system may have been responding rapidly to trigger El Nino conditions.
\end{abstract}

\section{Introduction}

Westerly wind events associated to perturbations of the large scale atmospheric convective activity may determine the onset of an El Niño [Mc Phaden, 1999; Mc Phaden and Yu, 1999; Boulanger and Menkes, 1999] by forcing oceanic Kelvin waves in the equatorial Pacific. Indeed, satellite and in-situ observations indicate a connection between the occurrence and intensity of westerly wind events and the onset of warm ENSO events [Slingo and Delecluse, 1999] such as the 1997-1998 El Niño [Yu and Rienecker, 1998; Mc Phaden, 1999; Boulanger and Menkes, 1999]. Various studies have investigated the spatio-temporal structures of westerly wind events [Giese and Harrison, 1991; Harrison and Giese, 1991; Harrison and Vecchi, 1997], their impact in the observed oceanic vertical structure [Cronin et al., 2000; Delcroix et al., 1993], in simple oceanic models [Kessler and McPhaden, 1995; Boulanger and Menkes., 2001] or in more complex ones [Kindle and Phoebus, 1995; Richardson et al., 1995]. More precisely, studies based on linear wave theory have emphasized the role of oceanic Kelvin waves such as those forced by WWE in displacing the EEWP via their geostrophic zonal currents [Picaut et al., 1996; Picaut and Delcroix, 1995]. In particular, various authors [Mc Phaden, 1999; Boulanger and Menkes, 1999] have suggested that the strong March 1997 WWE (Figure 1) forced an observed strong Kelvin wave whose directly associated geostrophic zonal current anomalies advected the eastern edge of the warm-pool eastward and, thus, potentially initiated an ocean-atmosphere feedback leading to the largest El Niño on record Niño [Mc Phaden, 1999].

Copyright 2001 by the American Geophysical Union.

Paper number $2000 \mathrm{GL} 012364$.

0094-8276/01/2000GL012364\$05.00

\section{Oceanic response to the March 97 Westerly Wind Event}

\subsection{Ocean model and data variability}

In order to investigate the actual role of the March 1997 WWE, a first simulation is performed with the ORCA-OPA Ocean General Circulation Model [Madec et al., 1998; Madec and Imbard, 1996] starting in 1993, and using the observed ERS wind stress data [Bentamy et al., 1996] and climatological heat and water fluxes computed from the 1980-1993 ECMWF Reanalysis. A flux correction term is also computed as a relaxation of model temperature to Reynolds SST observations using a $-40 \mathrm{~W} / \mathrm{m}^{2} / \mathrm{K}$ coefficient. The OPA model has been shown to have a good skill in simulating the subsurface equatorial temperature and zonal current structure and variability, as well as surface currents and sea level during the 1997-1998 period when forced by the ERS wind stress data [Vialard et al., 2001]. This gives us confidence in interpreting the simulated processes as relevant for the real ocean. In the following, we will focus on the ocean surface variability. Figure 2 displays the observed and simulated sea surface temperatures on March, $10^{\text {th }} 1997$ as well as the simulated salinity and zonal current fields (observations are weekly data, and model outputs are 5-day averaged). The $28^{\circ} \mathrm{C}$ isotherm (Figures 2a-b) together with strong salinity and zonal current fronts were located at the dateline prior to the maximum of the March 1997 WWE (Figures 2c-d). One month later, both model and data show that large SST anomalies (larger than $1.5^{\circ} \mathrm{C}$ for both sets) are observed from the dateline to $160^{\circ} \mathrm{W}$ (Figures 2e-f). These anomalies are confined in a $3^{\circ} \mathrm{N}-3^{\circ} \mathrm{S}$ narrow band around the equator. The model indicates that these anomalies are actually the result of a zonal displacement of the EEWP by currents larger than $1 \mathrm{~m} / \mathrm{s}$ (Figure $2 \mathrm{~h}$ ) which are confined in a 50-m deep surface layer (not shown). These currents also advected the salinity front (Figure $2 \mathrm{~g}$ ) into the equatorial saltier waters of the central Pacific (Figure 2c). The major difference between the model and data SST anomalies is in their respective maximum (larger than $1.5^{\circ} \mathrm{C}$ in data and $2.5^{\circ} \mathrm{C}$ in the model). The large convective activity at that time near the dateline (McPhaden, 1999), the gaps in the TAO moorings at the dateline in March 1997 together with the spatial smoothness of the Reynolds SST data may contribute to the smaller amplitude of the observed positive anomalies. Anyway, aside from the $1^{\circ} \mathrm{C}$ difference, the major point highlighted by both model and data is the eastward displacement of the EEWP that linear theory alone cannot explain as will be shown later. 


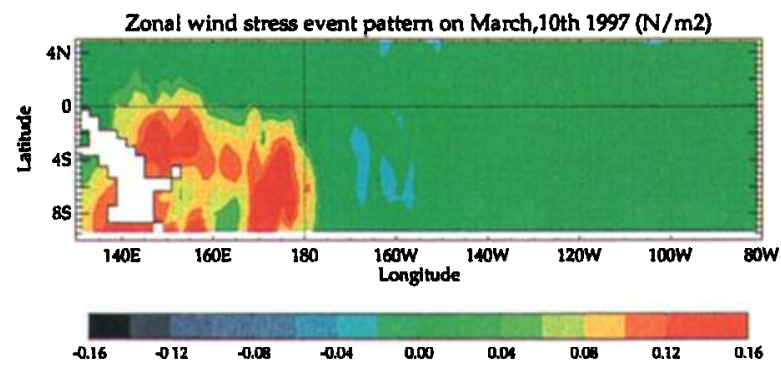

Figure 1. Spatial pattern of the March 1997 wind event on the 10 th of March as computed from the Local Modal Analysis method. Color intervals are every $0.02 \mathrm{~N} / \mathrm{m}^{2}$.

\subsection{Impact of the March 1997 Westerly Wind Event}

To document the oceanic response to the March 1997 WWE, a second simulation was performed using ERS wind stress data to which the March 1997 WWE is taken out of the wind forcing field. In order to extract specifically the spatio-temporal structure of this wind event near the equator, a Local Mode Analysis [LMA; Goulet and Duvel, 2000] was applied to the zonal and meridional wind stress for the equatorial zone $\left(5^{\circ} \mathrm{S}-5^{\circ} \mathrm{N} ; 120^{\circ} \mathrm{E}-\right.$ $250^{\circ} \mathrm{E}$ ) with a spatial resolution of $1^{\circ}$ and with a time window of 140 days. The wind event appears to be the most persistent signal
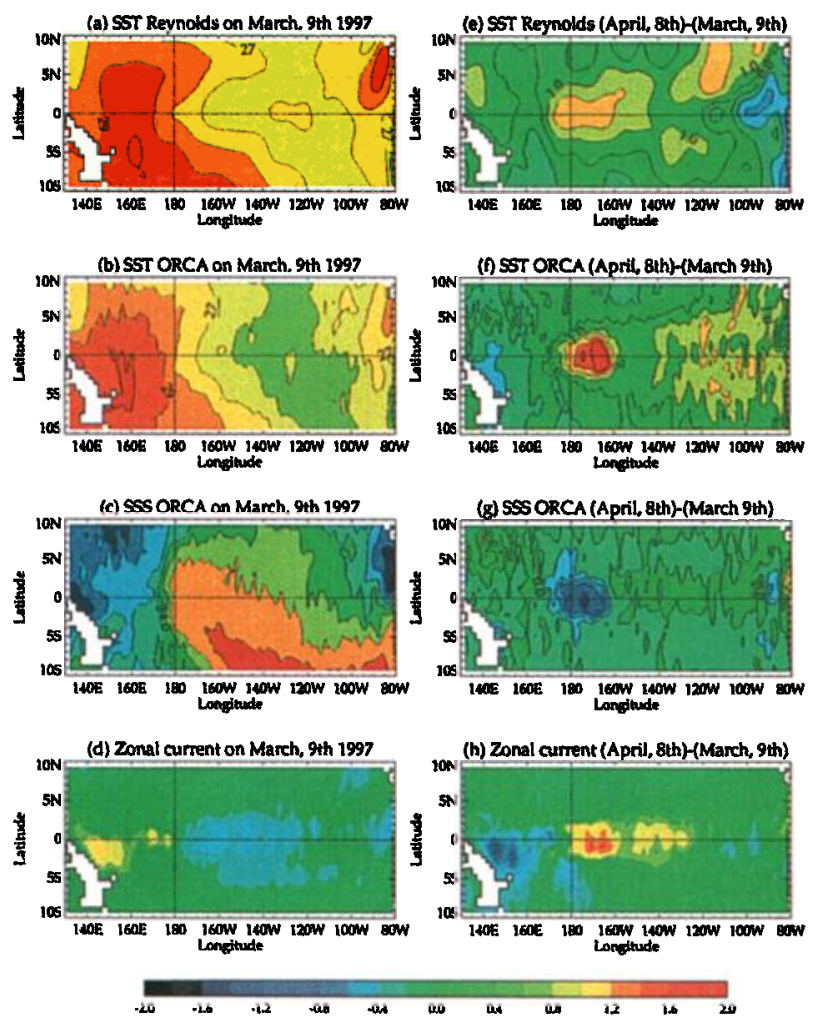

Figure 2. Spatial patterns of respectively (a) Reynolds sea surface temperature, (b) model sea surface temperature, (c) model sea surface salinity and (d) model surface zonal currents on March $9^{\text {th }}, 1997$, and of anomalies in (e) Reynolds sea surface temperature, (f) model sea surface temperature, (g) model sea surface salinity and (h) model zonal current computed as the differences between April 8th and March 9th conditions. Contour/color intervals are every $1{ }^{\circ} \mathrm{C}$ in $(\mathrm{a}, \mathrm{b}), 0.5^{\circ} \mathrm{C}$ in $(\mathrm{e}, \mathrm{f})$, $0.5 \mathrm{psu}$ in $(\mathrm{c}, \mathrm{g})$, and $20 \mathrm{~cm} / \mathrm{s}$ in $(\mathrm{d}, \mathrm{h})$. for a time window centred on the $3^{\text {rd }}$ of March 1997 with a nearequatorial maximum in the western Pacific on the $10^{\text {th }}$ of March 1997. The wind event has a maximal amplitude (and is almost stationary) west of the dateline. The largest westerly wind perturbation near the equator is located near $150^{\circ} \mathrm{E}$ and a secondary maximum is located near $170^{\circ} \mathrm{E}$ (Figure 1).

In order to only diagnose the impact of the wind event on the oceanic response, the heat and water fluxes in the second simulation are identical to the one used in the first simulation. It is important to note that, in the first simulation, a flux correction term was computed as a relaxation of model temperature to Reynolds SSTs using a $-40 \mathrm{~W} / \mathrm{m}^{2} / \mathrm{K}$ coefficient. To perform the second simulation, this term was added to the ECMWF heat forcing prior to performing the second simulation which thus does not use any specific restoring term. This procedure allows the model SST in that second simulation to adjust freely to dynamical changes. The difference between the two simulations thus traces the source of the changes in the equatorial Pacific Ocean conditions due only to the dynamical perturbation generated by the March 1997 WWE. The differences between the two simulations are now examined along the equator (Figures 3 ).
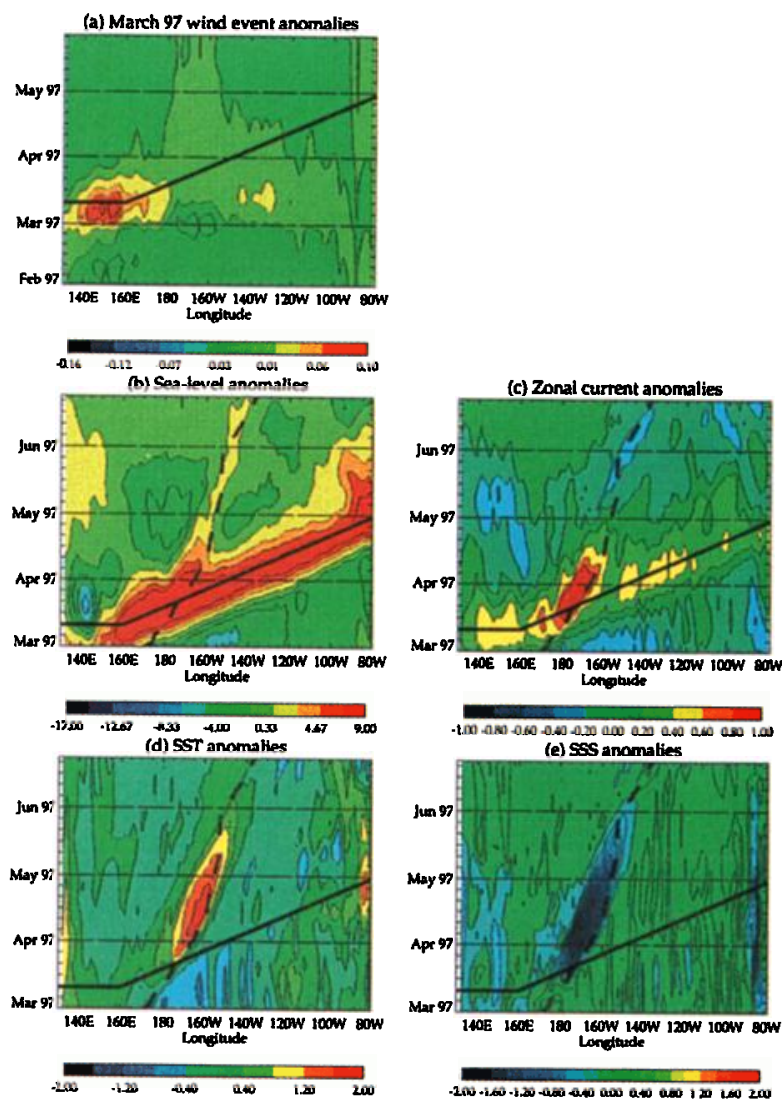

Figure 3. Longitude-time plots of the $2^{\circ} \mathrm{N}-2^{\circ} \mathrm{S}$ averaged differences between the two simulations for zonal wind stress of (a) zonal wind stress (color intervals are every $0.02 \mathrm{~N} / \mathrm{m}^{2}$ ), (b) sea level (color intervals are every $2 \mathrm{~cm}$ ), (c) zonal current (color intervals are every $20 \mathrm{~cm} / \mathrm{s}$ ), (d) sea surface temperature (color intervals are every $0.5^{\circ} \mathrm{C}$ ) and (e) sea surface salinity (color intervals are every $0.40 \mathrm{psu}$ ). The straight line represents the trace of the Kelvin wave propagation from the eastern edge of the wind event. The dashed line is the $1021.5 \mathrm{~kg} / \mathrm{m}^{3}$ isopycne which characterizes well the eastern edge of the warm-pool simulated in the control run. 
The equatorial maximum in the westerly wind stress anomalies, observed on the beginning of March around $150^{\circ} \mathrm{E}$ (Figure 3a), forces a large downwelling Kelvin wave (Figure $3 \mathrm{~b}$ ) propagating to the eastern Pacific at a phase speed around $2.8 \mathrm{~m} / \mathrm{s}$ (straight line). Although an SST anomaly is observed at the very eastern boundary (Figure 3d) in direct association with the Kelvin wave, in agreement with suggestion by data [Boulanger and Menkes, 1999] and other ocean model studies [Boulanger and Menkes, 2000], the main SST anomaly is observed at the eastern edge of the warm-pool. Simultaneously, a strong sea surface salinity (SSS) signal (Figure 3e) is observed as well at this edge. These SST and SSS signals are displaced more or less at the same velocity $(\sim 1 \mathrm{~m} / \mathrm{s})$. This is much faster than the speed of the geostrophic zonal current anomaly of about $35-40 \mathrm{~cm} / \mathrm{s}$ produced by the Kelvin wave only (Figure $3 \mathrm{c}$ ). This fast propagation is related to a large eastward zonal current perturbation $(\sim 1 \mathrm{~m} / \mathrm{s})$ propagating from March $15^{\text {th }}$ to April $15^{\text {th }}$ at the same speed as the SST and SSS signals along the eastern edge of the warmfresh pool (Figure 3c). Although these large eastward zonal current anomalies are initiated when the Kelvin wave passes the dateline, where the salinity front is initially located (Figure $2 \mathrm{c}$ ), the simultaneous evolution of SST, SSS and zonal current anomalies continue while the Kelvin wave moves faster further east. The coupled displacement of the equatorial dynamical and thermodynamical fronts while the Kelvin wave is gone thus cannot obey to linear dynamics.

\section{Non-linear mechanism of displacement of the eastern edge of the warm-pool}

In order to investigate the mechanisms responsible for the large zonal current response near the dateline, the contributions of each term of the zonal momentum equation at the surface are examined. The major terms contributing to the zonal current variability (Figure 4) are the zonal advection of zonal momentum, the zonal pressure gradient and the difference between the zonal wind stress and the vertical friction term over the $10 \mathrm{~m}$-thickness of the first level of the model. All other terms are negligible and will not be discussed. From these results, we can draw the following scenario: (i) in response to the westerly winds, a downwelling Kelvin wave is forced and propagates eastward (Figure 3b); (ii) a zonal pressure gradient associated to the Kelvin wave propagation generates an acceleration of the currents west of the Kelvin wave front (Figures $3 c$ and 4c); (iii) the zonal current increases near the convergence front due to the wave propagation. Initially, at this front, zonal currents are close to zero, and the zonal gradient of zonal currents is negative (Figure 2d). Therefore a non-linear response takes place (Figure 4b) when positive current anomalies induced by the passing Kelvin wave interact with the negative zonal current gradient at the convergent front. This interaction strongly increases the zonal current; (iv) the temperature and salinity fronts are displaced by zonal advection via the enhanced zonal current and generate a zonal pressure gradient moving eastward (Figure 4c); (v) the zonal pressure gradient at the edge of the warm-fresh pool as well as the non-linear term of momentum advection (Figure $4 \mathrm{~b}$ ) both contribute to increase the zonal current locally as the front moves eastward. Such a process is maintained during about a month while the vertical diffusion acts against it and increases its negative feedback when the $3^{\circ} \mathrm{N}-3^{\circ} \mathrm{S} / 50$-m deep fronts propagate eastward over colder and saltier waters associated to westward zonal currents [Vialard and Delecluse, 1998a,b].
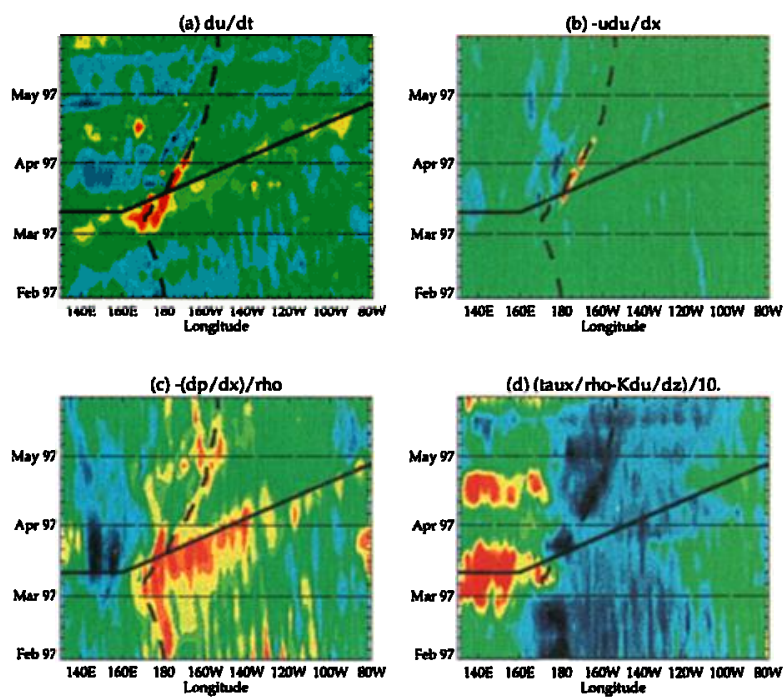

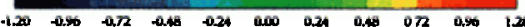

Figure 4. Longitude-time plots of the $2^{\circ} \mathrm{N}-2^{\circ} \mathrm{S}$ averaged trends of the zonal momentum equation: (a) zonal current derivative, (b) zonal advection of zonal momentum, (c) zonal pressure gradient, (d) difference over the $10 \mathrm{~m}$-thickness of the model first level between the zonal wind stress and the vertical diffusion. Color intervals are every $0.12(\mathrm{~m} / \mathrm{s}) /$ month. The straight line represents the trace of the Kelvin wave propagation from the eastern edge of the wind event. The dashed line is the $1021.5 \mathrm{~kg} / \mathrm{m}^{3}$ isopycne which characterizes well the eastern edge of the warm-pool simulated in the control run.

\section{Discussion}

Our results showed that the simulated displacement of the eastern edge of the warm-pool in March-April 1997 is much larger than the one which would have been induced by the geostrophic zonal currents associated to the wind-forced downwelling Kelvin wave. While Kelvin waves contribute as an initiating process, the non-linear interaction of equatorial dynamical and thermodynamical fronts at the EEWP is an essential process in extending eastward the warm-fresh pool during the onset phase of the 1997-1998 El Niño. This non-linear interaction is by far the largest signal in response to the March 1997 westerly wind event with associated space and time scales to which the atmosphere is likely to respond in that sensitive region.

Finally, this result suggests that the displacement of the warmfresh pool is strongly dependent on the oceanic conditions at the EEWP prior to the wind event and more precisely to the strength of the dynamical and thermodynamical fronts. A better knowledge of such oceanic conditions (through an assimilation of oceanic observations and an improvement in surface forcings) is of crucial importance to improve ENSO predictions. This supports the need for a global/accurate observation system of the ocean, including measurements of sea surface salinity in the Tropics. Last but not least, the potentially important role of the tightness of the salinity front in the strength of the non-linear interaction highlights the needs for improvements in the knowledge and simulation of the hydrological cycle. 
Acknowledgments. We are thankful to the Institut National des Sciences de l'Univers (INSU) and the Programme National d'Etude de la Dynamique du Climat (PNEDC) for their financial support, as well as to the Institut du Développement et des Ressources en Informatique Scientifique (IDRIS) for providing supercomputing facilities. We also thank R. Reynolds and T. Smith at NOAA/NCEP for SST data and the Center ERS d'Archivage et de Traitement located in the Institut Francais de Recherche pour l'Exploitation de la Mer for providing the processed and gridded ERS-1 and ERS-2 zonal wind stress data.

\section{References}

Bentamy, A., Y. Quilfen, F. Gohin, N. Grima, M. Lenaour, and J. Servain. Determination and validation of average wind fields from ERS-1 scatterometer measurements, The Global Atmopshere and Ocean System, 4, 1-29, 1996.

Boulanger, J.-P., and C. Menkes, Long equatorial wave reflection in the Pacific Ocean from TOPEX/POSEIDON data during the 1992-1998 period, Clim. Dyn., 15, 205-225, 1999.

Boulanger, J.-P., et C. Menkes, The TRIDENT Pacific model. Part Il : The thermodynamical model and the role of long equatorial wave reflection during the 1993-1998 TOPEX/POSEIDON period, Clim. Dyn., 17, 175-186, 2001.

Cronin, M. F., M. J. McPhaden, and R. H. Weisberg, Wind-forced reversing jets in the western equatorial Pacific, J. Phys. Oceanogr., 30 , 657-676, 2000.

Delcroix, T., G. Eldin, M. J. McPhaden, and A. Morlière, Effects of westerly wind bursts upon the western equatorial Pacific Ocean, February-April 1991, J. Geophys. Res., 98, 16,379-16,385, 1993.

Giese, B. S., and D. E. Harrison, Eastern equatorial Pacific response to three composite westerly wind types, J. Geophys. Res., 96, 3239-3248. 1991.

Goulet, L., and J.P. Duvel, A new approach to detect and characterise intermittent atmospheric oscillations: Application on the Intraseasonal Oscillation, (To Appear in the J. Atmos. Sci.), 2000.

Harrison, D.E, and B. S. Giese, Episodes of surface westerly winds as observed from islands in the western tropical Pacific, J. Geophys. Res., 96, 3221-3237, 1991

Harrison, D. E., and G. A. Vecchi, Surface westerly wind events in the tropical Pacific, 1986-1995, J. Clim., 10, 3131-3156, 1997.

Kindle, J. C., and P. A. Phoebus, The ocean response to operational westerl wind bursts during the 1991-1992 El Niño, J. Geophys. Res., 100, 4893-4920, 1995

Kessler, W. S.., M. J.. McPhaden, and K. M. Weickmann, Forcing of intraseasonal Kelvin waves in the equatorial Pacific, J. Geophys. Res., $100,10,613-10,631,1995$
McPhaden, M. J., Genesis and evolution of the 1997-1998 El Niño, Science, 283, 950-954, 1999.

McPhaden, and X. Yu, Equatorial waves and the 1997-1998 El Niño, Geophys. Res. Letters, 26, 2961-2964, 1999.

Madec, G., P. Delecluse, M. Imbard, and C. Lévy, OPA 8.1 Ocean General Circulation Model reference manual. Note du Pôle de modélisation, Institut Pierre-Simon Laplace, N¹1, 91pp, 1998

Madec G., and M. Imbard, A global ocean mesh to overcome the North Pole singularity, Clim. Dyn., 12, 381-388, 1996

Picaut, J., M. Ioualalen, C. Menkes, T. Delcroix, and M. J. McPhaden, Mechanism of the zonal displacements of the Pacific warm pool: implications for ENSO, Science, 274, 1486-1489, 1996.

Picaut, J., and T. Delcroix, Equatorial wave sequence associated with warm pool displacements during the 1986-1989 El Niño-La Niña, $J$. Geophys. Res., 100, 18393-18408, 1995.

Richardson, R. A., I. G. Ginis, and L. M. Rothtsein, A numerical investigation of the local ocean response to westerly wind burst forcing in the western equatorial Pacific, J. Phys. Oceanogr., 29, 1334-1352, 1999.

Slingo, J., and P. Delecluse, Scale interactions and the tropical atmosphere-ocean system. Proceedings of a conference on the TOGA Coupled Ocean-Atmosphere Response Experiment (COARE), WCRP107, 59-69, 1999.

Vialard, J., C. Menkes, J.-P. Boulanger, P. Delecluse, E. Guilyardi and M. J. McPhaden, Oceanic mechanisms driving the SST during the 19971998 EI Niño, J. Phys. Oceanogr., in press, 2001.

Vialard, J., and P. Delecluse, An OGCM study for the TOGA decade. Part I: Role of salinity in the physics of the western pacific fresh pool. J. Phys. Oceanogr., 28, 1071-1188, 1998a.

Vialard, J., and P. Delecluse, An OGCM study for the TOGA decade. Part II: Barrier-layer formation and variability, J. Phys. Oceanogr., 28, 1089-1106, 1998b.

$\mathrm{Yu}, \mathrm{L}$. and $\mathrm{M}$. Rienecker, Evidence of an extratropical atmospheric influence during the onset of the 1997-1998 El Niño, Geophys. Res. Letters, 25 (18), 3537-3540, 1998.

J.-P. Boulanger, E. Durand, C. Menkes, P. Delecluse, M. Imbard, M Lengaigne, G. Madec and S. Masson, Laboratoire d'Océanographie Dynamique et de Climatologie, UMR CNRS/IRD/UPMC, Université Pierre et Marie Curie, Tour 26/Etage 4/Case100, 4 Place Jussieu, 75252 Paris, Cedex 05, France. (e-mail: jpb, durand, menkes, pna, mi, lengaign, gm or smasson@lodyc.jussieu.fr)

J.-P. Duvel, Laboratoire de Meteorologie Dynamique, ENS, 24, Rue Lhomond, 75231 - Paris Cedex 05, France. (e-mail: jpduvel@Imd.ens.fr)

(Received August 23, 2000; accepted January 2, 2001) 